\title{
Single-Cell Transcript Profiling of Barley Attacked by the Powdery Mildew Fungus
}

\author{
Torben Gjetting, ${ }^{1}$ Peter H. Hagedorn, ${ }^{1}$ Patrick Schweizer, ${ }^{2}$ Hans Thordal-Christensen, ${ }^{1}$ \\ Timothy L. W. Carver, ${ }^{3}$ and Michael F. Lyngkjær ${ }^{1}$ \\ ${ }^{1}$ Biosystems Department, Risø National Laboratory, DK-4000 Roskilde, Denmark; ${ }^{2}$ Institute of Plant Science and \\ Crop Research, D-06466, Gatersleben, Germany; ${ }^{3}$ Institute of Grassland and Environmental Research, Aberystwyth, \\ Ceredigion, SY23 3EB, U.K.
}

Submitted 8 August 2006. Accepted 22 September 2006.

\begin{abstract}
In many plant-pathogen interactions, there are several possible outcomes for simultaneous attacks on the same leaf. For instance, an attack by the powdery mildew fungus on one barley leaf epidermal cell may succeed in infection and formation of a functional haustorium, whereas a neighboring cell attacked at the same time may resist fungal penetration. To date, the mixed cellular responses seen even in susceptible host leaves have made it difficult to relate induced changes in gene expression to resistance or susceptibility in bulk leaf samples. By microextraction of cell-specific mRNA and subsequent cDNA array analysis, we have successfully obtained separate gene expression profiles for specific mildew-resistant and -infected barley cells. Thus, for the first time, it is possible to identify genes that are specifically regulated in infected cells and, presumably, involved in fungal establishment. Further, although much is understood about the genetic basis of effective papilla resistance associated with mutant mlo barley, we provide here the first evidence for gene regulation associated with effective papilla-based nonspecific resistance expressed in nominally "susceptible" wild-type barley.
\end{abstract}

Additional keywords: gene ontology, KEGG.

Barley powdery mildew is caused by Blumeria graminis $\mathrm{f}$. $\mathrm{sp}$. hordei, an obligate fungal biotroph forming haustoria that extract nutrients from within host epidermal cells to generate ectophytic hyphae and airborne spores. Hypersensitive host cell death (preventing biotrophy) due to race-specific ( $R$ gene) resistance has proved ephemeral because $B$. graminis f. sp. hordei populations rapidly evolve virulence. Even in susceptible barley, haustorium formation depends on epidermal cell wall penetration from appressoria (infection structures), and many cells resist penetration. This penetration resistance is associated with cell wall changes and formation of papillae (local-

Corresponding author: M. F. Lyngkjaer; E-mail: m.lyngkjaer@risoe.dk

T. Gjetting and P. H. Hagedorn contributed equally to this work.

Current address of T. Gjetting: Kennedy Institute, 2600 Glostrup, Denmark.

Current address of H. Thordal-Christensen: Plant and Soil Sciences, Department of Agricultural Sciences, Faculty of Life Sciences, University of Copenhagen, DK-1871 Frederiksberg C, Denmark.

* The $\boldsymbol{e}$-Xtra logo stands for "electronic extra" and indicates the HTML abstract available on-line contains supplemental material not included in the print edition. Information about additional array results and three additional tables appear on-line. ized cell wall appositions) that reinforce attack sites (Zeyen et al. 2002). In some host genotypes, the proportion of penetration-resistant cells is substantial, conveying a high level of race-nonspecific, durable resistance. Where haustoria do form, host cells must survive both the physical intrusion and redirection of metabolism. Survival may depend on the pathogen's ability to avoid triggering or to suppress host defenses, perhaps by targeting specific host genes or proteins (Lyngkjær and Carver 1999; Mendgen and Hahn 2002). Therefore, it is important to stress here that an attacked barley leaf necessarily contains a mix of cells with quite different immediate histories; some have no direct pathogen contact (including all mesophyll cells), some have resisted penetration, and others contain functional haustoria. The genetic and metabolic processes differentiating penetration-resistant and infected cells are poorly understood, but they are undoubtedly subtle and complex.

Plant responses to pathogens involve regulation of particular genes, with the temporal and spatial context of activity determining whether defense is effective or not (Glazebrook 2001; Rushton and Somssich 1999). Northern blot analyses (Collinge et al. 1994), using mRNA from bulk extracts of whole leaves or, at best, dissected epidermal tissue, confound the genetic activity present in cells of different types and histories. Therefore, this approach provides crude information obscuring spatial relationships and considers only a few genes. With the advent of microarray technology, expression profiles for thousands of genes are now examined routinely in many plant species, including barley, by oligonucleotide and cDNA microarrays (Caldo et al. 2004; Zierold et al. 2005). Again, however, analyses based on bulk extracts would obscure vital spatial details of responses to $B$. graminis f. sp. hordei. Clearly, measurements of gene expression in individual attacked host cells of known response phenotype are necessary for informed interpretation.

Collection of sufficient mRNA from individual cells is a major obstacle for large-scale gene expression profiling (Iscove et al. 2002). One approach is to use capillary extraction (Brandt et al. 1999, 2002; Gjetting et al. 2004; Karrer et al. 1995; Mould et al. 2003). It is then necessary to amplify the nucleic acids without affecting quantitative differences in native transcript abundance. This has been achieved using as little as 10 pg (approximately 1 cell) before exponential amplification (Iscove et al. 2002). Using capillary extraction and exponential amplification, we recently assessed cell-specific expression of 20 selected genes in the barley epidermis and demonstrated differences between infected, resistant, and unattacked epidermal cells (Gjetting et al. 2004). This established the principle and reliability of the approach and opened the way for more extensive analysis. 
Here, we analyzed material by large-scale gene transcript profiling on the Gatersleben barleyPGRC1 10,000 cDNA arrays (10K array). Profiles were derived from $B$. graminis f. sp. hor$d e i$-infected cells, papilla-containing penetration-resistant cells, and unattacked cells. Differentially expressed genes were identified and a number were mapped to metabolic pathways (Kyoto Encyclopedia of Genes and Genomes [KEGG]) (Kanehisa and Goto 2000). In addition, overrepresented biological processes, cellular components, or molecular functions were identified using gene ontology terms (Ashburner et al. 2000).

Our approach identifies key genes and processes related to nonspecific penetration resistance and susceptibility to $B$. graminis f. sp. hordei, and can be applied to a number of other systems requiring high resolution of events and processes.

\section{RESULTS}

\section{Extraction and amplification of single-cell material.}

Individual resistant and infected epidermal cells of the susceptible barley line Pallas were easily distinguished by microscopy of living barley leaves $18 \mathrm{~h}$ after B. graminis f. sp. hordei inoculation (Gjetting et al. 2004). The presence of a papilla subtending the primary appressorial lobe and formation of a second lobe was used to recognize and select resistant cells: a second lobe forms only when an effective host cell papilla prevents attempted penetration from the first. Infected cells were recognized by presence of a rudimentary fungal haustorium. The contents of individual resistant cells, infected cells, and uninoculated control cells were collected in microcapillaries. The mRNA in the samples was captured immediately on magnetic beads, purified, and, after cDNA synthesis and polymerase chain reaction (PCR) amplification, processed for the hybridization experiments.

\section{Preservation of expression profile after PCR amplification.}

Even though others (Iscove et al. 2002; Karrer et al. 1995) have used similar amplification methods and shown that the relative abundance of different transcripts was conserved, for completeness we verified that this also was true for our amplification protocol. We extracted and pooled material from 30 infected and 30 control cells. One-third of the material from each of these pools was combined to create a new, mixed sample. Thus, this sample represented a biological average of the samples representing pure infected and control material. The resulting three samples, each equivalent to 20 cells' contents,

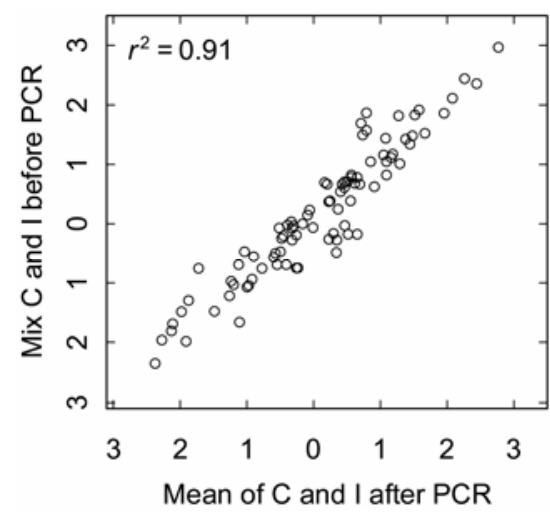

Fig. 1. Validation of polymerase chain reaction (PCR) amplification. Three samples were prepared: a control sample (C), a sample from infected cells (I), and a sample containing a 1:1 mix of the infected and control cell samples (Mix C and I). After amplification, the expression of 91 genes was measured in each of the three samples. The average of the expression intensities of these genes in the infected and control samples ( $x$-axis) are plotted against the mix of infected and control sample ( $y$-axis). then were PCR amplified and hybridized to small dotblot arrays spotted with 91 expressed sequence tags (ESTs) isolated from $B$. graminis-infected barley cells (Gjetting et al. 2004). It was known that these 91 genes are expressed to different degrees in infected cells, and that approximately one-third are clearly differentially expressed between the infected and control cells (data not shown). If the amplification step preserved the original abundance relationship, then the expression of each gene measured in the mixed sample should be similar to the average expression in infected and control material. In turn, this would indicate that relative expression levels are preserved during amplification of the mixed sample. This is clearly the case for the entire range of expressions intensities (Fig. 1). This demonstrated that different genes having different expression patterns and levels were amplified to a reasonably equal degree (coefficient of determination $\left[r^{2}\right]=0.91$ ) and that the PCR procedure maintained relative transcript abundance levels.

\section{The $10 \mathrm{~K}$ array hybridization and data preprocessing.}

As part of the EST sequencing effort conducted at the Institute of Plant Genetics and Crop Plant Research, Germany (Künne et al. 2005), a cDNA array spotted with 10,297 unique PCR fragments was manufactured (Gatersleben barley PGRC1 $10 \mathrm{~K}$ array) (Sreenivasulu et al. 2002). Of these, 10,072 constitute a cDNA clone collection of a corresponding number of unique barley genes, the remaining 225 being putative $B$. graminis f. sp. hordei clones (a description of how this distinction between plant and fungi clones was made is provided in Materials and Methods). Only the barley genes were used in the following analyses. When comparing the genes on our array with the genes on the Affymetrix Barley Genome Array (Close et al. 2004), $15 \%$ of the genes are unique to our array. These unique genes are derived primarily from barley infected with powdery mildew (HO library) (Zierold et al. 2005) and are, therefore, particularly valuable to our study.

Using standard procedures, we hybridized 12 arrays with radioactively labeled material from the cell-specific samples: three with material from resistant cells, three with material from infected cells, three with material from noninoculated control cells, and three identical samples for technical replication, made by pooling equal amounts of material from the three infected samples. Following autoradiography by phosphorimaging, the gene expressions from each hybridized array were quantified using data preprocessing and normalization protocols specifically optimized to our cDNA array technology and to the subsequent data analysis (discussed below). All raw and normalized data are stored in the ArrayExpress database accession number E-MEXP-457.

\section{Identification of global differences \\ between the cell-specific samples.}

To visualize the relationships between samples, hierarchical clustering and multidimensional scaling (MDS) (Cox and Cox 2000) were used. Hierarchical clustering arranges similar samples close together in a tree structure, and MDS places the samples in a three-dimensional space where similar samples are close together. Thus, neither method imposes any structure on the data beforehand-both are simply ways of visualizing the relations between the samples by reducing the dimensionality. The result is shown in Figure 2. This shows clearly that the control samples (blue) are separated from the resistant (green) and infected samples (red and pink). The infected and resistant samples also are separated, but to a lesser degree. Furthermore, it is noteworthy that the technical replicates of the infected samples (pink) are placed as a tight cluster in the middle of the group of infected samples (red), confirming the reproducibility of the $10 \mathrm{~K}$ array. 
The clear separation between control, resistant, and infected samples indicates that i) a large number of genes are induced or repressed or ii) affected genes display large changes in expression.

\section{Detection of candidate genes and their regulation.}

Differential expression between infected or resistant samples compared with control samples was assessed using the $\mathrm{R}$ software package LIMMA (Gentleman et al. 2004; Smyth 2004). This package implements a multivariate statistical method that uses all nine arrays simultaneously to judge statistical significance. Briefly, for each gene, empirical Bayesmoderated $F$ statistics were used to test for changes between infected or resistant samples compared with control samples. Genes were considered significantly regulated if the $P$ values adjusted for multiple testing (Benjamini and Hochberg 1995), were less than 0.05 . The false discovery rate (FDR) was limited to less than 5\%. Using this method, 332 genes were found to be regulated significantly by powdery mildew attack.

The expression profiles of the 332 candidate genes are shown in a heatmap (Fig. 3A) and ordered according to their regulation in a Venn diagram (Fig. 3B). The Venn diagram shows that 46 genes were upregulated only in samples from infected cells, 98 genes were upregulated only in resistant cell samples, and 54 genes were upregulated in both infected and resistant cell samples. The numbers of downregulated genes were consistently smaller. Here, 22 genes were downregulated
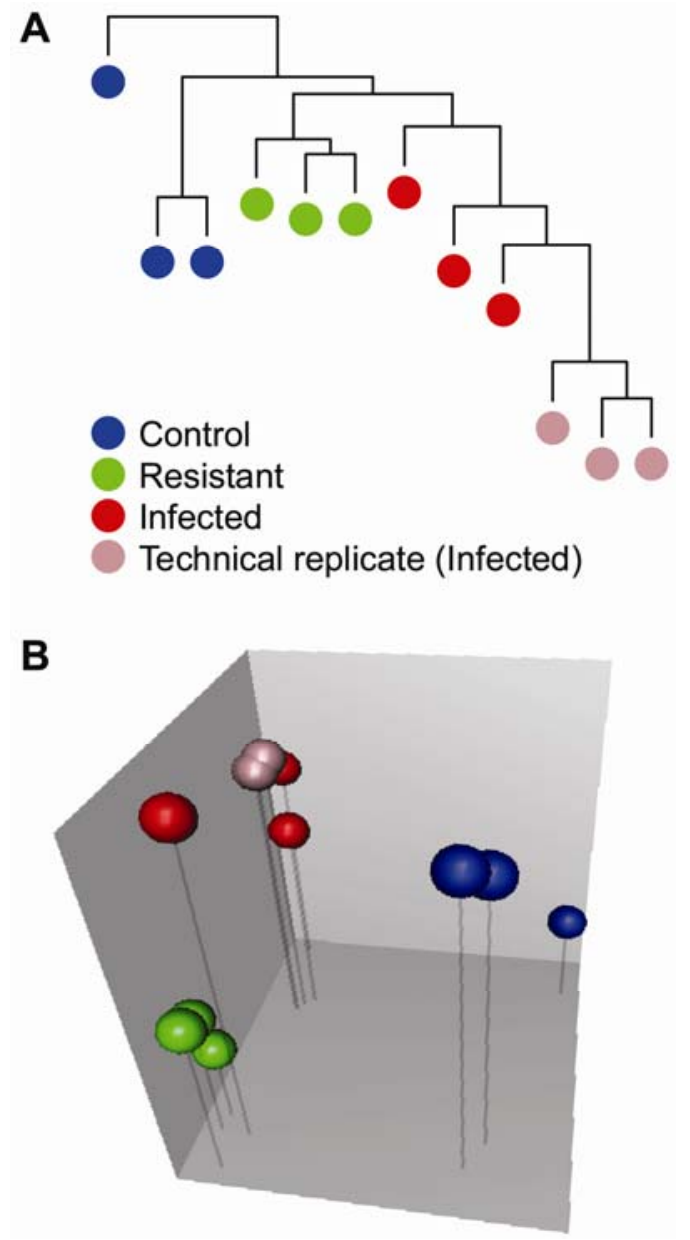

Fig. 2. Global differences between samples from infected, resistant, and control cells. A, Hierarchical clustering and $\mathbf{B}$, multidimensional scaling plot of all samples, both based on Euclidean distances calculated using all expression intensities measured in all samples. only in infected cells, 73 genes were downregulated only in resistant cells, and 40 genes were downregulated in both infected and resistant cells. No genes were found to be regulated in opposite directions in infected and resistant cells. Thus, our data suggest that, in general, if a gene is affected in both types of cells, it is regulated in the same direction. Notice also that, on the $10 \mathrm{~K}$ array, more genes were regulated in resistant cells (265 genes) than in infected cells (162 genes).

\section{Functional classification}

of candidate genes and mapping to pathways.

Using EST sequence reads from the crop EST database CREST (Künne et al. 2005), genes on the $10 \mathrm{~K}$ array were annotated
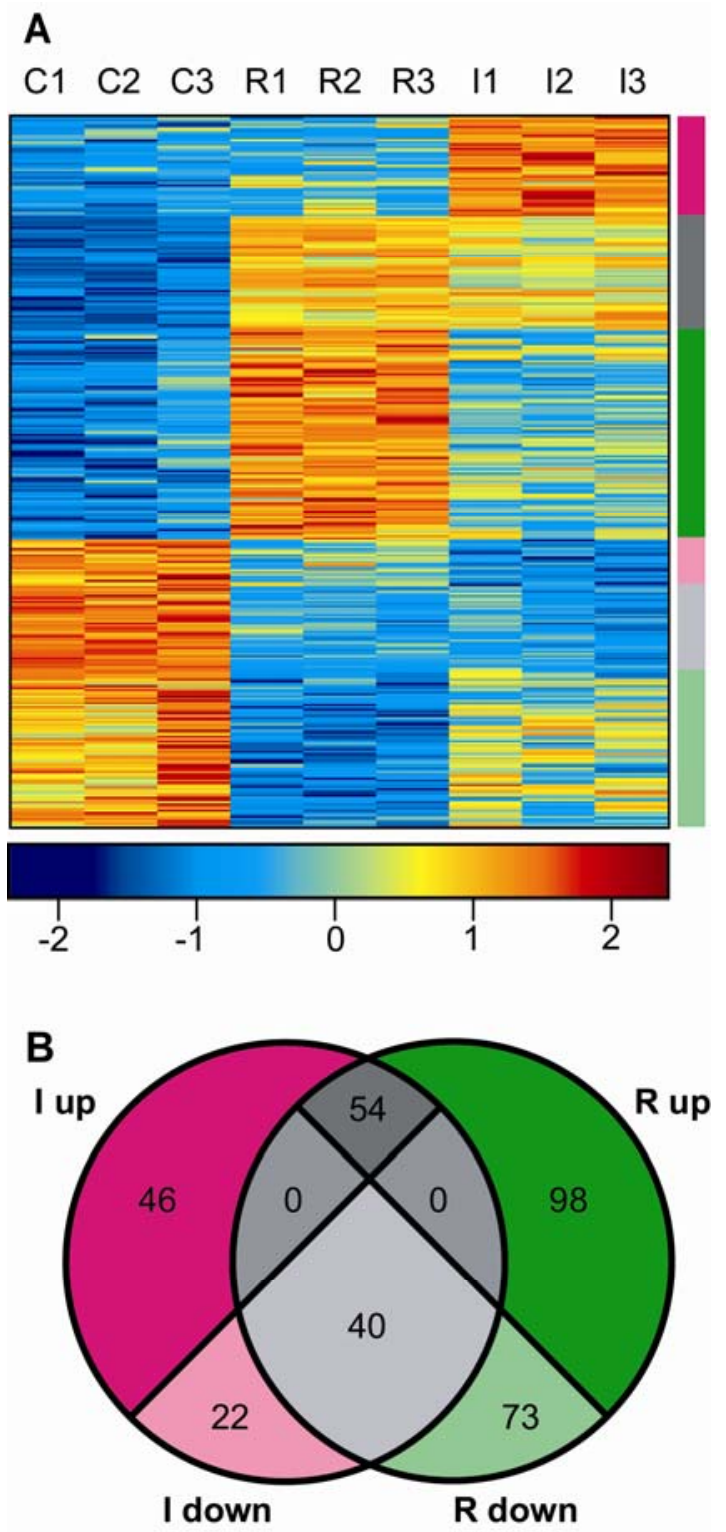

Fig. 3. Candidate genes and their regulation. A, Heat map of the 332 most significantly (false discovery rate $<0.05$ ) differentially expressed genes. The dark red color signifies high expression whereas the deep blue color signifies low expression relative to the general expression of each gene. Each column represents a sample and each row represents all expressions for a given candidate gene. The differential expression pattern is clearly seen and can be divided into six main patterns of regulation. B, Venn diagram grouping the candidate genes according to the six regulation types. The numbers in each part of the Venn diagram represents the number of genes with the given type of regulation; $\mathrm{C}=$ control sample, $\mathrm{R}=$ resistant sample, and $\mathrm{I}=$ infected sample. 
Table 1. Presumed gene function of candidate genes listed according to functional classification and the observed regulation ${ }^{\mathrm{a}}$

\begin{tabular}{|c|c|c|c|}
\hline \multirow[b]{2}{*}{ Reg. ${ }^{b}$} & \multirow[b]{2}{*}{ Functional classification } & \multicolumn{2}{|c|}{ Presumed gene function (expressed sequence tag clone name) } \\
\hline & & Upregulated $^{\mathrm{c}}$ & Downregulated \\
\hline I & Amino acid metabolism & Homocitrate synthase (HO13G05) & \\
\hline I & Cell wall & $\ldots$ & $\begin{array}{l}\text { 1-4- } \beta \text {-Glucanase (HY02N05), 1-3- } \beta \text {-glucanase } \\
\text { (HK04O19, HK04P09) }\end{array}$ \\
\hline I & DNA/chromatin structure & $\begin{array}{l}\text { DNA polymerase } \varepsilon \text { (HB01A20), histone } \mathrm{H} 3 \text { (HO08K10, } \\
\text { HO12D13), histone H4 (HO11P23), nonhistone protein } 6 \\
\text { (HO14L07) }\end{array}$ & the \\
\hline I & Glycolysis & Pyruvate decarboxylase $(\mathrm{HW} 03 \mathrm{I} 02 *)$ & $\ldots$ \\
\hline I & Heat shock (chaperone) & HSP70 (HO11L14*, HO14N21*) & \\
\hline I & Lipid metabolism & $\beta$-Keto acyl reductase (HW03O04) & GDSL-like lipase (HK03H24) \\
\hline I & Major carbohydrates & Sucrose synthase (HU03P12*, HY10G10*) & $\ldots$ \\
\hline I & Minor carbohydrates & .. & $\beta$-Fructofuranosidase (HT02H23) \\
\hline I & mRNA processing & $\begin{array}{l}\text { RNA helicase DBP5 (HO12B20), RNA-binding protein } \\
\text { (HO10B19) }\end{array}$ & 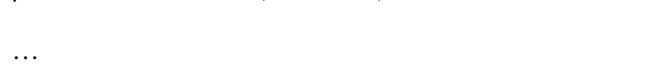 \\
\hline I & Nucleotide metabolism & CTP synthase (HW07A08) & $\ldots$ \\
\hline I & Oxidase & Peroxidase (HW03O08) & Peroxidase (HO10F22) \\
\hline I & Photosynthesis & $\ldots$ & Ribulose-1,5-bisphosphate carboxylase (HO04J20) \\
\hline I & Protease & $\ldots$ & $\begin{array}{l}\text { Serine protease (HK04D23), cysteine protease } \\
\text { (HK03G06) }\end{array}$ \\
\hline I & Protein synthesis & $\begin{array}{l}\text { RPL16 (HO07B10*), RPL10 (HO12G10*), RPP0 } \\
\text { (HO09D04*), RPS18AP (HO13N09*), RPS28 } \\
\text { (HO12H08*), RPL20BP (HO09N01*), RPL2BP } \\
\text { (HO06G08*), RPL33BP (HO03K13*), RPL37A } \\
\text { (HO10I03*), eIF3 (HO13B05), eIF4A (HO07B21), } \\
\text { RPL18 (HO15L08*), RPS15 (HO10A15*), RPL7a } \\
(\text { HY10C21*), eEF1 } \alpha(\text { HO07O11*) }\end{array}$ & $\cdots$ \\
\hline I & Redox & $\begin{array}{l}\text { Oxidoreductase (HO06K05), glutaredoxin (HA04P20), } \\
\text { GST (HD02A06) }\end{array}$ & \\
\hline I & Secondary metabolism & .. & $\begin{array}{l}\text { Carotenoid 9,10-9',10' cleavage dioxygenase (HO05G14), } \\
\text { O-methyltransferase (HK06E02, HO11A17) }\end{array}$ \\
\hline I & Signaling & GSP1P (HO06D22) & $\begin{array}{l}\text { Farnesylated protein } 2 \text { (HO03N23), CTTP (HW03I23, } \\
\text { HT01C05), receptor-protein kinase (HO07E04) }\end{array}$ \\
\hline I & Stress-related & FIERG2 (HO02F02) & $\ldots$ \\
\hline I & Transport & Potassium transporter $(\mathrm{HO} 11 \mathrm{~F} 02)$ & $\ldots$ \\
\hline IR & Cell organization & $\ldots$ & Formin (HK04G04) \\
\hline IR & Cell wall & & Phytochelatin synthetase (HO07L18) \\
\hline IR & Development & $\begin{array}{l}\text { C-hordein (HF01P09), late embryogenesis abundant } \\
\text { protein (HY08A20) }\end{array}$ & AmA1 (HV01D21, HO06J02, HK04E01) \\
\hline IR & DNA/chromatin structure & Origin recognition complex subunit 2 (HO07A10) & DDR48 (HG01P09) \\
\hline IR & Energy & Malate dehydrogenase (HK04F13) & $\ldots$ \\
\hline IR & Glycolysis & $\begin{array}{l}\text { GAPDH (HO04H22), Phosphoglycerate dehydrogenase } \\
\text { (HH01B10) }\end{array}$ & . \\
\hline IR & Heat shock (chaperone) & $\begin{array}{l}\text { CCT4 (HO05L14*), GRP94 (HD02O01*), Disulfide } \\
\text { isomerase (HY02J22) }\end{array}$ & $\begin{array}{l}\text { Heat shock protein (HK04G01, HO01L09), } \\
\text { low-temperature induced protein (HK04I03) }\end{array}$ \\
\hline IR & Hormone metabolism & $\ldots$ & CIG3 (HY08H13) \\
\hline IR & Lipid metabolism & $\ldots$ & Lipase (HO10J20, HO05D07) \\
\hline IR & mRNA processing & CSFS1 (HY08P19*) & $\ldots$ \\
\hline IR & Nodule-factor & $\ldots$ & ENOD93A (HV01F21) \\
\hline IR & Nucleotide metabolism & Nucleoside Hydrolase (HH02M14) & $\ldots$ \\
\hline IR & Oxidase & $\begin{array}{l}\text { Germin }\left(\mathrm{HO} 03 \mathrm{H} 17^{*}, \mathrm{HO} 1 \mathrm{~B} 21^{*}, \mathrm{HO} 09 \mathrm{I} 08^{*}\right) \text {, peroxidase } \\
\text { (HW05C10, HO02P04, HW03P04*, HV02L18*, } \\
\text { HW09H06, HO13D15) }\end{array}$ & \\
\hline IR & Photosynthesis & $\ldots$ & Glycerate dehydrogenase (HO13N23*, HO10C24*) \\
\hline IR & Protease & $\ldots$ & $\begin{array}{l}\text { Cysteine protease (HK04C12, HP01O19, HF01P06, } \\
\text { HO11F18) }\end{array}$ \\
\hline IR & Protein degradation & Glycine-rich protein (HO13I11*) & \\
\hline IR & Protein synthesis & eEF1 $\alpha(\mathrm{HO} 01 \mathrm{P} 12 *)$ & RPS27 (HO05L12) \\
\hline IR & Protein targeting & $\ldots$ & GDSL-like lipase (HV01D23) \\
\hline IR & Redox & $\begin{array}{l}\text { ATX1 (HO12C16), cytochrome P450 (HO04H15), } \\
\text { NADPH:quinone oxidoreductase (HH02O14), GST } \\
\text { (HS01J15, HO05C22), iron/ascorbate-dependent } \\
\text { oxidoreductase (HW05I22) }\end{array}$ & $\begin{array}{l}\text { GST (HK05M13), thiamine biosynthetic enzyme } \\
\text { (HY09L03*, HV04H14*), dihydroflavonol 4-reductase } \\
\text { (HY09015) }\end{array}$ \\
\hline IR & Secondary metabolism & $\ldots$ & $\begin{array}{l}\text { Phosphoethanolamine methyltransferase (HF01L22*, } \\
\text { HO09G03*) }\end{array}$ \\
\hline IR & Signaling & $\begin{array}{l}\text { Coatomer (HO14M22), TIC62 (HO05L24), zinc finger } \\
\text { protein } 14(\mathrm{HO} 12 \mathrm{O} 11) \text {, guanine nucleotide-binding } \\
\text { protein } \beta\left(\mathrm{HY} 08 \mathrm{~F} 21^{*}\right)\end{array}$ & Phosphoinositide kinase (HO05J14) \\
\hline IR & Stress-related & $\begin{array}{l}\text { PR17B (HP01C14*, HT01E04*), PR-10A (HO06C19), } \\
\text { PR17A (HW03J02) }\end{array}$ & $\begin{array}{r}\text { Gibberellic acid inducible protein (HO12B09) } \\
\text { (continued on }\end{array}$ \\
\hline
\end{tabular}

\footnotetext{
a Additionally, 83 genes with unknown function also were significantly regulated.

${ }^{\mathrm{b}}$ Regulated in infected cells (I), both infected and resistant cells (IR), and resistant cells (R).

${ }^{\mathrm{c}}$ Candidate genes with assigned gene ontology terms that are overrepresented are indicated with an asterisk.
} 
Table 1. (continued from preceding page)

\begin{tabular}{|c|c|c|c|}
\hline \multirow[b]{2}{*}{ Reg. $^{b}$} & \multirow[b]{2}{*}{ Functional classification } & \multicolumn{2}{|c|}{ Presumed gene function (expressed sequence tag clone name) } \\
\hline & & Upregulated $^{c}$ & Downregulated \\
\hline IR & Transcriptional regulation & $\ldots$ & bHLH9 (HO06C07) \\
\hline IR & Transport & $\begin{array}{l}\text { Amino acid transporter }(\mathrm{HO} 01 \mathrm{I} 10), \text { phosphate } \\
\text { transporter } 6\left(\mathrm{HM} 1 \mathrm{E} 09^{*}\right), \text { hexose transporter } \\
\left(\mathrm{HW} 05 \mathrm{O} 02^{*}, \mathrm{HO} 12 \mathrm{~F} 18^{*}\right), \text { chloride transporter } \\
(\mathrm{HO} 06 \mathrm{~F} 14)\end{array}$ & v-ATPase B (HO10E13) \\
\hline $\mathrm{R}$ & Amino acid activation & $\begin{array}{l}\text { Asparaginyl-tRNA synthetase (HW02E23), glutamine } \\
\text { synthetase (HO14C08), GAD1 (HP01N05, } \\
\text { HO07F11) }\end{array}$ & $\cdots$ \\
\hline $\mathrm{R}$ & Amino acid metabolism & $\ldots$ & Shikimate kinase (HW08C23) \\
\hline $\mathrm{R}$ & Cell organization & $\begin{array}{l}\text { Lipid transfer protein 7a2b (HO02B06), kinesin } \\
\text { (HY09K04) }\end{array}$ & Actin depolymerizing factor 5 (HW09A18) \\
\hline $\mathrm{R}$ & Cell wall & $\begin{array}{l}\text { 1-3- } \beta \text {-Glucanase (HO04F09), Pectinesterase } \\
\text { (HY10N07) }\end{array}$ & . \\
\hline $\mathrm{R}$ & Development & - & $\begin{array}{r}\text { B12D (HY04P02), early embryogenesis protein } \\
\text { (HO14O16, HV01J01), hordein B (HB09A12) }\end{array}$ \\
\hline $\mathrm{R}$ & DNA/chromatin structure & $\ldots$ & MBD105 (HY08D12) histone H2A (HA06M19) \\
\hline $\mathrm{R}$ & Energy & Nicotinate-nucleotide pyrophosphorylase (HO01A07) & $\begin{array}{l}\text { Pyruvate dehydrogenase E1 } \alpha \text { (HW02P05), malate } \\
\text { dehydrogenase (HD01L03), } \gamma \text {-hydroxybutyrate } \\
\text { dehydrogenase (HO04B08) }\end{array}$ \\
\hline $\mathrm{R}$ & Gene transcription & $\cdots$ & $\begin{array}{l}\text { RNA binding protein (HT01M12), polypyrimidine } \\
\text { tract-binding protein (HW03M12) }\end{array}$ \\
\hline $\mathrm{R}$ & Glycolysis & $\ldots$ & Phosphoglycerate mutase (HW03L12) \\
\hline $\mathrm{R}$ & Heat shock (chaperone) & $\begin{array}{l}\text { GRP94-like protein (HA10E15, HO05L01), disulfide } \\
\text { isomerase (HY08O13), calnexin (HO13M03) }\end{array}$ & \\
\hline $\mathrm{R}$ & Hormone metabolism & $\begin{array}{l}\text { Ethylene-forming-enzym 1E (HW04K06, HO12L20, } \\
\text { HO06P13) }\end{array}$ & $\begin{array}{l}\text { 60-kDa jasmonate-induced protein (HV01J21), IAA1 } \\
\text { (HW06I24) }\end{array}$ \\
\hline $\mathrm{R}$ & Lipid metabolism & Lipase (HY08B02) & Squalene monooxygenase (HO14P22) \\
\hline $\mathrm{R}$ & Minor carbohydrates & $\alpha$-Galactosidase (HY02A06) & $\alpha-$ Galactosidase $(\mathrm{HY} 03 \mathrm{H} 07)$ \\
\hline $\mathrm{R}$ & mRNA processing & $\cdots$ & $\begin{array}{l}\text { KH domain protein (HU04C14), snRNP splicing factor } \\
\text { (HO09J01) }\end{array}$ \\
\hline $\mathrm{R}$ & Nucleotide metabolism & Pyrophosphatase (HW06I17) & .. \\
\hline $\mathrm{R}$ & Oxidase & Germin (HO01J19, HK04J17), peroxidase (HW02P13) & $\ldots$ \\
\hline $\mathrm{R}$ & Photosynthesis & Chloroplast hypothetical protein (HY07K03) & Chlorophyll A/B binding protein (HO01D10) \\
\hline $\mathrm{R}$ & $\begin{array}{l}\text { Post-translational } \\
\text { modification }\end{array}$ & Cis/trans-isomerase (HO04D22) & 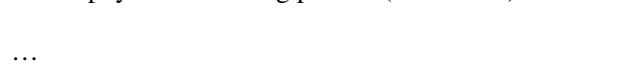 \\
\hline $\mathrm{R}$ & Protease & $\begin{array}{l}\text { Aspartyl protease (HO06C18), protease (HH01E05), } \\
\text { serine protease (HO14K19) }\end{array}$ & Cysteine protease (HK04I21) \\
\hline $\mathrm{R}$ & Protease inhibitor & $\alpha$-Amylase/subtilisin inhibitor (HY01O19) & Trypsin inhibitor (HT01P07) \\
\hline $\mathrm{R}$ & Protein degradation & Ubiquitin (HO07E03) & $\begin{array}{l}\text { Proteasome regulatory particle non-ATPase subunit } 12 \\
\text { (HS01F23, HH02K16) }\end{array}$ \\
\hline $\mathrm{R}$ & Protein synthesis & EF1 $\alpha$ (HO11L07), RPS2 (HY02C07) & Ribosomal protein (HO07D12), RPS18AP (HY10L24) \\
\hline $\mathrm{R}$ & Protein targeting & $\begin{array}{l}\text { ADP-ribosylation factor (HW02M24), vacuolor } \\
\text { sorting protein } 35 \text { (HO02F14) }\end{array}$ & ADP-ribosylation factor (HP01L19) \\
\hline $\mathrm{R}$ & Redox & $\begin{array}{l}\text { ATP-binding protein (HY04P18), ATX1 (HO12P07), } \\
\text { cytochrome P450 (HO04A04, HD02G17), GST } \\
\text { (HW07M12), MTN3 (HO01B14) }\end{array}$ & $\begin{array}{l}\text { GST (HW02N04), metallothionine (HY08L09), - } \\
\text { thionin (HT01P18) }\end{array}$ \\
\hline $\mathrm{R}$ & Secondary metabolism & $\begin{array}{l}\text { Caffeoyl CoA O-methyltransferase (HY03D14), } \\
\text { protein methylesterase (HY06B04) }\end{array}$ & $\begin{array}{l}\text { Cinnamyl-alcohol dehydrogenase (HY02M11), } \\
\text { hydroxymethylglutaryl-coa lyase (HO15G14), } \\
\text { isocitrate lyase (HV01F01), } \beta \text {-lycopene cyclase } \\
\text { (HO02K06), } \gamma \text {-hydroxybutyrate dehydrogenase } \\
\text { (HY07G17) }\end{array}$ \\
\hline $\mathrm{R}$ & Signaling & $\begin{array}{l}\text { ERD4 (HO02G23), farnesyltransferase (HW07B05), } \\
\text { MUTT (HO14D18), palmitoyl-protein thioesterase } \\
\text { (HO11K02), RAB7 (HO09E08), RAS2P (HO13L02), } \\
\text { receptor protein kinase (HY01A10), SECA } \\
\text { (HO15C19), serine/threonine protein kinase } \\
\text { (HO10I1, HO02A04, HO09A14), SERK2 } \\
\text { (HO14K22) }\end{array}$ & $\begin{array}{l}\text { COI1 (HO09I10), LRR protein (HO01G06), ABI3- } \\
\text { interacting protein (HS01F18, HH01G13), } \\
\text { serine/threonine protein kinase (HO05M11), BPW3 } \\
\text { (HW08O07) }\end{array}$ \\
\hline $\mathrm{R}$ & Stress-related & $\begin{array}{l}\text { HIR (HY08O21), 14-3-3a (HO05G22), PR4 } \\
\text { (HO07N02, HO13J17), salt tolerance protein } 4 \\
\text { (HO04B17), blue copper-binding protein (HW07I11, } \\
\text { HW07J04, HO11C07) }\end{array}$ & $\begin{array}{l}\text { Adenylate cyclase (HO08E05), drought inducible 22- } \\
\text { kDa protein (HO07P16, HO04M08), MIF (HW03J13) }\end{array}$ \\
\hline $\mathrm{R}$ & Transcriptional regulation & $\begin{array}{l}\text { F-box protein (HO03A05), SAR DNA binding protein } \\
\text { (HY02P09), zinc finger protein (HO04E02) }\end{array}$ & MADS-Box Protein 3 (HV01L15) \\
\hline $\mathrm{R}$ & Transport & $\begin{array}{l}\text { POTG (HY09K15), aldose 1-epimerase (HW08G11), } \\
\text { hexose transporter (HO15G24, HO02I03) }\end{array}$ & $\begin{array}{l}\text { Hexose transporter (HD01I14), permease } 1 \\
\text { (HO04P23), v-ATPase H (HM02K10), calcium } \\
\text { transporter (HK03J13), metal transporter (HO04O10) }\end{array}$ \\
\hline $\mathrm{R}$ & Vesicle transport & $\begin{array}{l}\text { 27k vesicle-associated membrane protein (HO03C03), } \\
\text { SEC6 (HO10F23) }\end{array}$ & AUT1 (HY02G09), $\alpha-S N A P(H O 05 I 13)$ \\
\hline
\end{tabular}


by a i) blastx (Altschul et al. 1990) search against the nonredundant (nr) protein database at GenBank to assign function by homology to similar genes, ii) tblastx search specifically against the Arabidopsis genome (The Arabidopsis Information Resource) to identify ortholog genes, and iii) blast search against the TIGR barley gene index database. The TIGR barley gene index constitutes an assembly of all available barley ESTs into contigs, and TIGR annotates these contigs using gene ontology (GO) terms and EC numbers when possible. Hence, using the mapping obtained by blast between genes on the $10 \mathrm{~K}$ array and TIGR contigs, GO terms were assigned to 4,868 genes on the array (47\%), and EC numbers to 1,446 genes on the array $(14 \%)$.

In addition to the functional classification of genes based on GO terms, the candidate genes also were classified into 33 different functional groups resembling the major functional classes in the MAPMAN system (Thimm et al. 2004). For those candidate genes where GO terms were available, the two methods of functional classification were, in general, overlapping and in conjunction. Also, for ease of reference, popular gene names were assigned to the candidate genes. All candidate genes, their regulation, popular name, and classification are listed in Table 1. All collected information on the candidate genes is available in Supplement 4.

For each type of regulation of the candidate genes (Fig. 3; each part of the Venn diagram), Fisher's exact test was used to test for overrepresentation of GO-defined biological processes, cellular components, or molecular functions between these genes and the remaining genes on the array. A GO term was judged as significantly overrepresented when the Bonferronicorrected $P$ value was less than 0.05 . For three types of regulation, significantly overrepresented GO terms were found: i) genes specifically upregulated in infected cells (7 GO terms), ii) genes upregulated in both infected and resistant cells (16 GO terms), and iii) genes downregulated in infected and resistant cells (5 GO terms). The most profound-yet not easily interpretable-finding is the statistical overrepresentation of 13 genes relating to protein biosynthesis (GO term 0006412) that are specifically upregulated in infected cells. However, in general, the overrepresented GO terms either simply confirm existing knowledge (for example, in compliance with the notion of localized cellular responses and biotic stress, genes coding for cellular components localized in the plasma membrane [GO term 0005886] and two peroxidases annotated by GO as responding to nematodes [GO term 0009624] are overrepresented among genes upregulated in both infected and resistant cells) or are not obviously related to our system (for example, a guanine nucleotide-binding protein $\beta$ annotated as "oviposition" [GO term 0018991] is overrepresented among genes upregulated in infected and resistant cells). All significantly overrepresented GO terms are presented in Supplement 2. For easy cross-reference, candidate genes annotated with GO terms that are significantly overrepresented are marked with an asterisk after the clone number in Table 1.

A comprehensive mapping of enzymatic pathways is compiled in the KEGG. The mapping of genes to pathways is based on EC numbers. However, among the 332 candidate genes, only 64 have been assigned with an EC number. Therefore, for this analysis only, we set the significance threshold to FDR $<0.15$ instead of FDR $<0.05$, thus including 774 genes with 136 having an EC number. A list with all 774 genes used in this analysis, along with their regulation, is found in Supplement 3 . We note with interest that metabolic pathways involving energy production, sugar conversions, and phenylpropanoid biosynthesis appear to be regulated differently between infected, resistant, and control cells. The significance will be discussed below.
Validation of single-cell data by comparison with bulk extracts.

Direct confirmation of all candidate gene expressions in individual resistant and infected cells (e.g., by in situ hybridization or single-cell real-time PCR) would be extremely laborious and, crucially, carry implicit dangers of artifactual effects. An alternative is to compare candidate gene expression with expression data obtained using RNA bulked from dissected epidermal tissue or whole leaves from similar barley- $B$. graminis f. sp. hordei interactions. As emphasized above, such data are not as specific as single-cell data. However, because no genes were found to be regulated in opposite directions in infected and resistant cells, we expect that most genes, if detectable, are regulated in the same direction in single-cell and bulk sample extracts. Also, most importantly, use of bulk sample extracts avoids potential artifactual effects on transcript abundance that may be introduced during amplification of mRNA from very small amounts. Thus, comparison with bulk sample extracts would serve not only to validate data for regulation of our candidate genes but also to validate the single-cell analysis approach in general. Consequently, we compared our single-cell data with bulk sample results obtained independently using the $10 \mathrm{~K}$ array, the Affymetrix Barley Genome Array, and reverse-transcription-PCR (RT-PCR) tests for 10 selected genes.

For comparison with the $10 \mathrm{~K}$ array, we considered data obtained using dissected epidermal tissue from an unpublished larger experiment performed at the Gatersleben laboratory (A. Himmelbach and P. Schweizer, personnel communication). Here, the epidermal tissue was sampled at $24 \mathrm{~h}$ after inoculation (hai), whereas our single-cell study extracts were made at 18 hai. Taking the ratio of mean gene expression from inoculated compared with noninoculated material (four replicates of each) provided regulation data that could be compared with the single-cell data. This analysis confirmed regulation of 287 of our 332 candidate genes (i.e., a confirmation rate of $86 \%$ ) (Fig. 4A).

Whole-leaf data were available from a timecourse study performed by Caldo and associates (2004) using the Affymetrix Barley Genome Array. Using blastn, we determined the probesets on the Affymetrix array corresponding to the candidate genes on the $10 \mathrm{~K}$ array. For these probesets, we then determined which were significantly differentially expressed (using a $t$ test with $P$ values corrected for multiple testing less than $0.05)$ between noninoculated and inoculated whole-leaf material extracted at 20 hai. The results are shown in Figure 4B. Of the $54 \%$ of the candidate genes that were significantly regulated, $77 \%$ confirmed the regulation found in our single-cell study. For these, $90 \%$ also were confirmed by the $10 \mathrm{~K}$ array data; therefore, the confirmed regulations are highly overlapping.

We consider that confirmation rates of 77 to $86 \%$ are sufficiently high to impart confidence in the regulatory information derived from single-cell analyses. This is underlined by the fact that the comparisons were derived i) from different laboratories and array platforms and with somewhat different experimental protocols, ii) using RNA bulked from epidermal tissues as well as whole leaves, iii) using slightly different timepoints during the interaction, and iv) with different genotypes of barley and powdery mildew fungus. Some of the gene regulations that could not be confirmed in bulk extracts could be due to the fact that differential expression of many genes can be detected only in single-cell material and not in bulk samples (Gjetting et al. 2004).

To further confirm the observed regulation of the candidate genes, we performed a simple RT-PCR test for 10 of these that are predominantly known to be pathogenesis-related genes (Gjetting et al. 2004). Expressions of these genes were tested 
in total RNA from B. graminis f. sp. hordei-inoculated or uninoculated barley leaf material that was harvested 18 hai. The results confirmed the upregulation of seven and downregulation of two of three of the genes (i.e., a confirmation rate of $90 \%)$. The results from all three comparisons are included in the list with candidate genes provided in Supplement 4.

\section{DISCUSSION}

In many host-pathogen systems, quite different outcomes may result from pathogen attacks on different host cells. Thus, even in "compatible" B. graminis f. sp. hordei-barley interactions, some leaf epidermal cells are infected while others resist penetration. In bulk samples, this mix of outcomes has hindered attempts to relate changes in gene regulation to resistance or susceptibility (Lyngkjær and Carver 1999). Here, we overcame this problem by cell-specific mRNA collection and subsequent cDNA array analysis to obtain expression profiles of many different genes in samples from $B$. graminis f. sp. hordei-infected and -resistant barley cells. For the first time, this allowed identification of candidate genes specifically regulated in infected host cells during haustorium formation and establishment of biotrophy. Further, although much is understood of the basis of penetration resistance in mutant mlo barley (Schulze-Lefert 2004), we provide here the first extensive analysis of gene regulation associated with cell-wall-based, nonspecific resistance in nominally "susceptible" wild-type barley.

Only two previous reports have considered cell-specific gene expression in plants attacked by pathogens, but both involved very few genes. Through EST sequencing, Mould and associates (2003) focused on discriminating early events asso- ciated with susceptibility or hypersensitive resistance in the cowpea rust system. In total, only 38 plant genes were found to be regulated. By blast analysis, we found that only seven of these had barley homologues represented on the $10 \mathrm{~K}$ array, none of which were regulated by $B$. graminis f. sp. hordei attack. Recently, Gjetting and associates (2004) studied effects of $B$. graminis f. sp. hordei attack on cell-specific regulation of 20 selected barley genes. The $10 \mathrm{~K}$ array carries 17 of these and, as reported, seven were upregulated after attack.

Based on their expression profiles and functional classification (Table 1), we can now relate the activity of some of these genes to known biological phenomena. However, this must be viewed in context: the array included only 10,073 of the 25,000 to 43,000 genes that barley is thought to contain, and we consider only those showing clear regulation. Hence, our candidates, at best, probably represent only 25 to $50 \%$ of all genes regulated in epidermal cells responding to B. graminis $\mathrm{f}$. sp. hordei attack.

\section{Regulation in infected cells.}

Cells infected by $B$. graminis f. sp. hordei show massive cytological and metabolic reorganization. The site where cells are penetrated is sealed around the haustorial neck by a "collar" containing host-cell-deposited constituents, many of which also are found in effective papillae (Zeyen et al. 2002). Haustoria, contained within an invagination of the modified plant cell plasma membrane (the extrahaustorial membrane [EHM]), gain access to intracellular solute pools while redirected host metabolism supports generation of nutrients that enter haustoria via the EHM (Green et al. 2002; Panstruga 2003). Host cell survival under these stressful conditions must depend on the
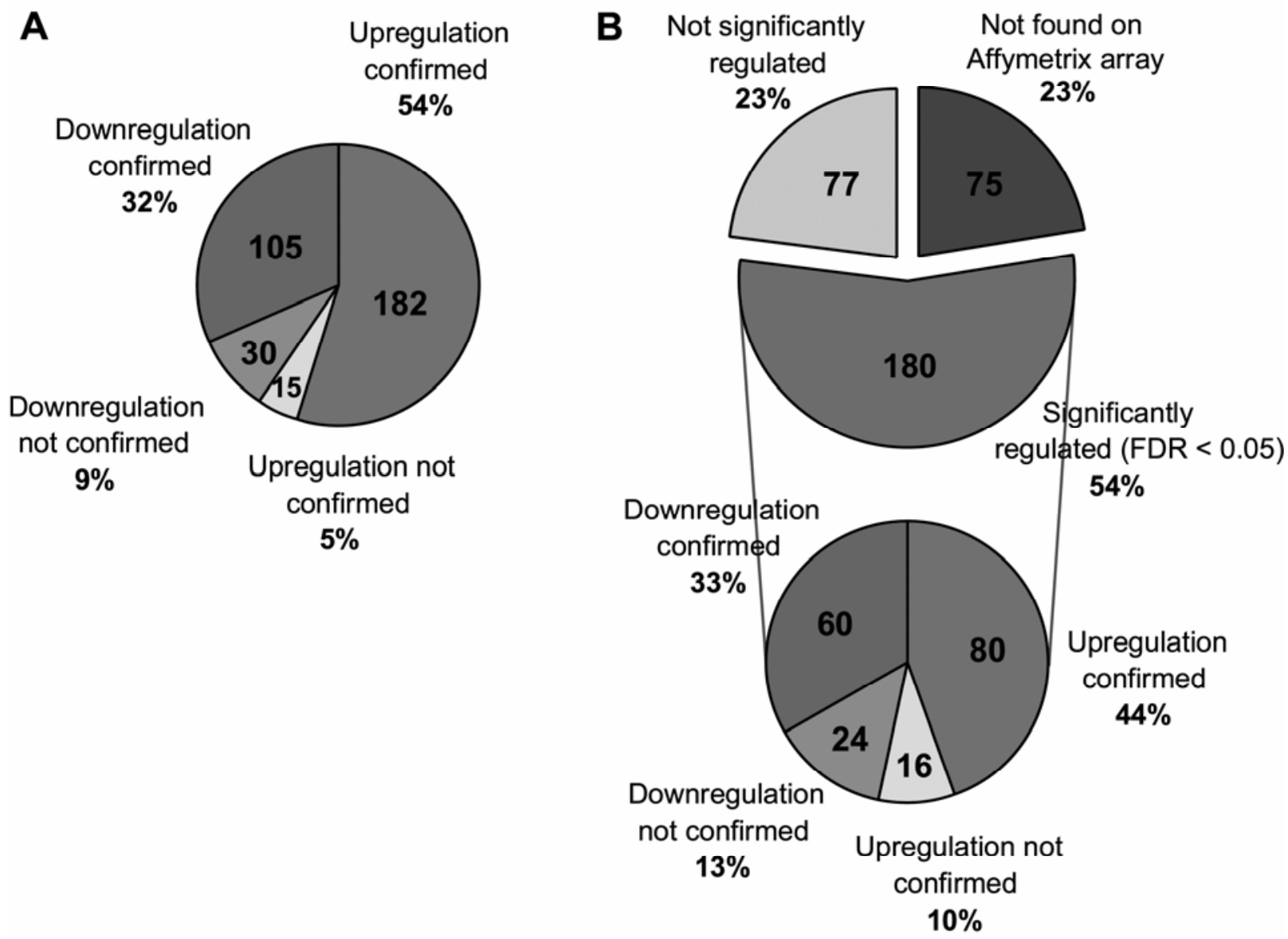

Fig. 4. Comparison of candidate gene regulations to regulations in bulk sample material. A, Dissected epidermal tissue (10k cDNA array) and $\mathbf{B}$, whole-leaf material (Affymetrix Barley Genome Array). 
pathogen's ability either to avoid triggering or to suppress host defenses, while nutritional demands of the parasitized cell must be maintained by import from underlying mesophyll. Hence, gene regulation in infected cells will reflect these numerous changes.

In the context of $B$. graminis f. sp. hordei nutrition, we provide the first evidence that upregulation of sucrose synthase (HU03P12 and HY10G10; refer to EST clone codes in Table 1 ) is exclusive to infected cells. Collinge and associates (1994) previously noted sucrose synthase upregulation following $B$. graminis f. sp. horde $i$ inoculation, but they used bulk leaf samples that also contained papilla-resistant cells; in these, we found no such effect. Sucrose synthase catalyses the reversible conversion of sucrose and UDP into fructose and UDP-glucose and could be involved directly in providing hexoses for the fungus by cleaving the imported sucrose. However, the induction of sucrose synthase also may increase the sink activity of the infected cell and, thereby, lead to increased carbon import from the underlying tissues. Recently, it was suggested that mannitol is the preferred storage carbohydrate in bean rust and also involved in host defense suppression (Voegele et al. 2005). However, we detected no transcriptional regulation of genes relevant to the transport or metabolic modification of mannitol or other polyols; therefore, the role of these compounds in B. graminis f. sp. hordei nutrition and host defense suppression remains unknown.

Our evidence also suggests factors that may support survival of infected epidermal cells. Two upregulated genes are annotated as heat shock protein (HSP) 70-like (HSP-70) genes (HO11L14 and HO14N21) and HSPs, often induced by biotic and abiotic stress, can prevent stress-induced cell death (Ravagnan et al. 2001). Conversely, in animals, the cysteine protease activity of caspases is associated with apoptosis (Philchenkov 2004) and our analyses revealed downregulated transcription of five different cysteine proteases. One of these was exclusive to infected cells (HK03G06) whereas four others were downregulated in both infected and resistant cells (HK04C12, HP01O19, HF01P06, and HO11F18). Plant orthologs of caspases have not yet been identified (Lam and del Pozo 2000); however, it is tempting to speculate that downregulation of the cysteine protease genes is involved in cell survival.

In rice, FIERG2 is rapidly induced following biotic stress (Kim et al. 2003) and putative orthologs are present in barley (HO02F02) and also in Arabidopsis (At3g55470), where it encodes a $\mathrm{C} 2$ domain-containing protein, presumably involved in intracellular calcium-dependent vesicle transport (Nagano et al. 1998). Using Genevestigator (Zimmerman et al. 2004) we found that, in Arabidopsis, At3g55470 is strongly induced by both biotic and abiotic stress (data not shown). Intriguingly, we found that the barley ortholog (HO02F02) was specifically upregulated in B. graminis f. sp. hordei-infected cells. Whether these genes facilitate cell survival is not known; however, their potential role in stress tolerance merits further investigation.

Cellular stress is commonly associated with generation of reactive oxygen species (ROS) and, at approximately 18 hai, superoxide anions accumulate transiently in host epidermal cell protoplasm associated with haustoria (Hückelhoven and Kogel 1998). Detoxification of ROS is integral to survival of stressed cells (Foyer and Noctor 2005) and this may explain the specific upregulation of a glutathione- $S$-transferase (GST) gene (HD02A06), an oxidoreductase (HO06K05), and a glutaredoxin (HA04P20) seen here in infected cells.

Infected cells showed upregulation of 15 genes encoding protein components of the translation apparatus. Sensing of and response to stress has been linked to initiation of translation in terms of ribosome recruitment to internal ribosome-entry sites and cap-independent translation (Holcik and Sonenberg 2005).
Regulation of ribosome biogenesis in yeast and mammalian cells is controlled by the target of rapamycin (TOR) enzyme (Inoki et al. 2005). Signal cues from external or internal factors, including stress, modulate the activity of TOR, which coordinately controls events of cell growth, protein synthesis, and cell death (Danial et al. 2003). We speculate that increased translational activity in infected cells simply reflects aspects of balance between nutrient requirement and survival of the cell.

\section{Regulation in resistant cells.}

Effective papillae are chemically complex apoplastic wall appositions whose deposition involves early generation of nitric oxide (Prats et al. 2005) and hydrogen peroxide (ThordalChristensen et al. 1997) and accumulation of various organic (e.g., proteins and phenolics) and inorganic components into a callose matrix (Zeyen et al. 2002). This complexity suggests that many genes are involved in papilla construction and associated cell-wall modification.

Cytoplasmic vesicles transport various constituents to papilla sites where plasma membrane docking involves SNARE (soluble $N$-ethylmaleimide sensitive factor attachment protein receptor) and SNAP (synaptosomal associated protein interactions before exocytosis and transfer of material to the apoplast (Collins et al. 2003). This aligns with our finding of upregulated SEC6 activity (HO10F23), a member of the exocyst complex involved in exocytosis (Wang et al. 2004). Furthermore, we found that $\alpha$-SNAP (HO05I13), a SNARE-domaincontaining protein involved in resolving the vesicle-membrane complexes (Weinberger and Gerst 2004), was downregulated in resistant cells. The decreased abundance of $\alpha$-SNAP may influence timing and dynamics of vesicle-membrane fusion and, hence, affect the deposition of extracellular material. Gene AUT1 (HY02G09), involved in autophagy, another vesicular trafficking phenomenon (Schlumpberger et al. 1997), also was downregulated in resistant cells. Thus, though not fully explained, the data clearly show regulation of several genes involved in vesicle trafficking of resistant cells.

Much physiological evidence indicates that phenylpropanoids related to lignin biosynthesis are associated with effective papillae (Zeyen et al. 2002). Previous evidence (Gjetting et al. 2004) indicated upregulation of phenylalanine ammonia lyase (PAL), the gateway enzyme to phenylpropanoid biosynthesis, in resistant cells. Although PAL (HO15O04) showed insufficiently changed regulation for automatic inclusion in our candidate list, its expression was clearly increased in such cells (uncorrected $P$ value $=0.03$ ). Further, resistant cells also showed upregulation of caffeoyl-CoA $O$-methyltransferase (HY03D14), an enzyme specific to the lignin pathway (Meyermans et al. 2000). Interestingly, although both of these genes were regulated only in resistant cells, infected cells showed downregulation of an $O$-methyltransferase gene, another enzyme specifically associated with lignin synthesis. Overall, therefore, these data support physiological studies.

Cytological evidence suggesting that effective papilla formation is promoted by localized $\mathrm{H}_{2} \mathrm{O}_{2}$ generation (ThordalChristensen et al. 1997; Zeyen et al. 2002) is supported by our finding that genes encoding a peroxidase (HW02P13) and germin-like proteins (HO01J19 and HK04J17) capable of generating $\mathrm{H}_{2} \mathrm{O}_{2}$ were specifically upregulated in resistant cells (Table 1). Further, Zhang and associates (2004) showed that $B$. graminis f. sp. hordei appressoria secrete extracellular catalase which may degrade $\mathrm{H}_{2} \mathrm{O}_{2}$ at the penetration site to facilitate infection. Thus, upregulation of host $\mathrm{H}_{2} \mathrm{O}_{2}$ production at attack sites could overcome the pathogen's degradation capacity and promote penetration resistance. As noted earlier, however, from the attacked cell's perspective, ROS are potentially toxic, and specific upregulation of a GST gene (HW07M12) in resis- 
tant cells may relate to $\mathrm{H}_{2} \mathrm{O}_{2}$ degradation and cell protection. Similarly, several cytochrome P450 genes appear to be involved in detoxification of various compounds (Forkmann and Heller 1999) and two of these were specifically upregulated in resistant cells (HO04A04 and HD02G17).

As noted, HSPs can prevent stress-induced cell death (Ravagnan et al. 2001) and analyses of B. graminis f. sp. hordei-attacked bulk samples (Ellgaard and Frickel 2003; Kalinski et al. 1995; Puig and Gilbert 1994; Walther-Larsen et al. 1993) showed upregulation of several genes that function as HSP chaperones or aid in protein folding in the endoplasmic reticulum. We found that several of these were upregulated only in resistant cells, suggesting their involvement in ameliorating stress conditions generated by the papilla defense. These included two GRP94-like proteins (HA10E15 and HO05L01), calnexin (HO13M03), and disulphide isomerase (HY08O13). Also upregulated were genes encoding blue copper-binding proteins (HW07I11, HW07J04, and HO11C07). These genes generally are induced after biotic or abiotic stress (Yang et al. 2002) but their induction after B. graminis f. sp. hordei attack has not been reported, and their role is unknown.

Mapping data to metabolic pathways (KEGG) suggested transcriptional enhancement of the TCA cycle and ATP production by upregulation of citrate synthase (E.C. 2.3.3.1, HW04K02 [at FDR < 0.15]) and malate dehydrogenase (E.C. 1.1.1.37, HK04F13). Stress-induced uncoupling of NADH production in the TCA cycle and oxidative phosphorylation in the electron transport chain is a well-described response in mitochondria (Møller 2001), where ROS induce expression of uncoupling protein and alternative oxidase (Smith et al. 2004). However, the genes encoding these two proteins were unaffected. It is possible, therefore, that induced expression of TCA cycle genes results in increased ATP production in mitochondria of resistant cells, and we speculate that this primes their ability to resist penetration attempted by later attacks on these cells (i.e., promotes "induced inaccessibility") (Lyngkjær and Carver 1999).

In the starch and sucrose metabolic pathway, KEGG mapping indicated that UDP-glucose 6-dehydrogenase (E.C. 1.1.1.22, HH01A03 [at FDR < 0.15]) was upregulated in resistant cells. Presumably, this enzyme converts UDP-glucose to UDP-D-glucuronate for pectin biosynthesis. The coincident downregulation of poly-galacturonase (E.C. 3.2.1.15, HX04D02 [at FDR < 0.15]), involved in pectin degradation, suggests changes that could lead to cell wall fortification by pectin enrichment (Vogel et al. 2004). In line with this argument, Arabidopsis knock-outs of a pectate lyase gene (E.C. 4.2.2.2) have increased cell wall pectate content and show enhanced powdery mildew resistance (Vogel et al. 2002). Furthermore, we found that a pectin esterase gene (HY10N07) is upregulated in resistant cells. This presumably also contributes to the cell-wall strengthening by pectin demethylation (Vogel et al. 2004). The importance of pectin is suggested further by the fact that $B$. graminis f. sp. hordei conidia contain pectinase (Suzuki et al. 1998), presumably because this conveys an evolutionary advantage in pathogenesis, perhaps in facilitating cell-wall penetration.

The gene for 1-3- $\beta$-glucanase (HO04F09), another cellwall-modifying enzyme, also was upregulated only in resistant cells. The enzyme degrades not only callose found in papillae, but also 1,3- $\beta$-glucan, a key component of fungal cell walls. The enzyme was known to be upregulated in bulk barley leaf samples after B. graminis f. sp. hordei attack (Gregersen et al. 1997) and to accumulate locally in wheat mesophyll cell walls attacked by Puccinia recondita (Hu and Rijkenberg 1998). Interestingly, we also found that two 1-3- $\beta$-glucanases (HK04O19 and HK04P09) and a 1-4- $\beta$-glucanase (HY02N05) are downregulated in infected cells. To determine whether glucanases are active against fungal cell wall polysaccharides and inhibit the pathogen (Theis and Stahl 2004), or whether their activity affects plant cell-wall-penetration resistance, awaits temporal and spatial examination of their hydrolytic activities in a highly complex polymer environment (Somerville et al. 2004).

\section{Genes regulated}

\section{in both infected and resistant cells.}

Expression of a number of genes was modified significantly and to a similar extent in both infected and resistant cells. This was true both for genes apparently related to infection and for genes related to defense.

Two hexose transporters (HO12F18 and HW05O02) were upregulated after attack in both infected and resistant cells. In infected cells, this could serve to satisfy the nutritional demands of the parasite and, in resistant cells, the upregulation could compensate for the increased energy demand during the defense reaction. The corresponding GO term (0015770: sucrose transport) also was significantly overrepresented in both cell types. Thus, it is not possible to attribute these observations simply to infection.

A number of defense-related genes encoding pathogenesisrelated proteins, peroxidases, and germin-like proteins also were regulated similarly in both infected and resistant cells. Cells were sampled 18 hai when cytological features first allowed identification of infected and resistant cells, and it is not surprising that these cells should show a large number of common responses during the early stages of pathogen attack. Indeed, much previous timecourse evidence from Northern blot analyses of bulk samples clearly shows that, although transcription of certain genes is upregulated from as early as 12 hai (when attack is initiated), it is impossible at this time to discriminate between responses in "resistant" and "susceptible" hosts (Gregersen et al. 1997). There are good reasons why this should be so. For instance, as noted previously, the chemical constitution of haustorial neck collars is, in many respects, qualitatively similar to that of effective papillae. Thus, the synthesis of common constituents, their transport to attack sites, and construction of the neck collar or papilla structures probably involves many common cellular activities. However, it may be anticipated that, after the outcome of attempted penetration is determined, the ongoing activities in infected and papilla-resistant cells will show increasing divergence over time. Because of the inability to predict the outcome of individual attacks before 18 hai, single-cell analyses before this time obviously would not help to resolve the role of common transcripts in determining resistance or infection. However, analyses following the course of transcriptional activity of infected cells as haustoria develop and grow are likely to elucidate the relevance of certain commonly regulated genes in biotrophic parasitism, (e.g., in suppressing defense responses and allowing continuing host cell survival).

Our approach has allowed the first large-scale identification of candidate genes regulated in barley leaf epidermal cells by $B$. graminis f. sp. hordei attack. It has enabled discrimination of activities in infected cells and those showing papilla-based, race-nonspecific resistance that is beyond the influence of single genes with major effect. The high spatial resolution provided gives new mechanistic insight into the barley $B$. graminis f. sp. hordei interaction. Importantly, the methods reported here can be applied directly to other plant-pathogen interactions and to analyses of plant developmental and physiological processes that also require single-cell discrimination of gene expression and regulation. 


\section{MATERIALS AND METHODS}

\section{Plants and fungi.}

Barley (Hordeum vulgare L.) cv. Pallas and the virulent powdery mildew fungus (B. graminis DC Speer f. sp. hordei) isolate A6 were used. Plants were grown to full expansion of first-formed leaves ( 7 days old) at $20 \pm 2^{\circ} \mathrm{C}$ and $250 \mu \mathrm{mol} \mathrm{m}$ $\mathrm{s}^{-1}$ photon flux density during an 18 -h light period, inoculated with approximately 60 mildew conidia $\mathrm{mm}^{-2}$, and incubated for a further $18 \mathrm{~h}$ before sampling.

\section{Microsampling.}

Individual barley epidermal cells that resisted fungal penetration (papilla present) and cells that had been infected (haustorium present) were identified by microscopy and their contents extracted separately by microcapillary (Gjetting et al. 2004). Extracts were exclusively from short epidermal cells that: had no contact with stomatal complexes, were attacked by a single appressorium, and had no other fungal contact within two cells' distance. Extracts from noninoculated barley provided controls. Extracts from five individual cells of the same type were delivered into extraction buffer within $60 \mathrm{~s}$ of commencing collection. Four of these then were combined before enzyme inactivation (see below) to give one sample containing extracts from 20 similar cells. Three independent biological replicates were prepared for each cell type. Furthermore, three technical replicates were prepared from the infected biological replicates by pooling equal quantities from each one and dividing this pooled sample into three.

\section{mRNA purification and cDNA synthesis.}

The mRNAs in extracts were captured immediately and purified on poly(dT) oligonucleotides coupled to magnetic beads using the Dynabeads mRNA DIRECT Micro Kit (Dynal, Oslo, Norway). First-strand cDNA synthesis on the magnetic beads was initiated within $8 \mathrm{~min}$ before processing, as described previously (Gjetting et al. 2004). Briefly, following first-strand and second-strand cDNA synthesis, extracts were purified and suspended in TE-t (10 mM Tris, $\mathrm{pH} 8.0 ; 1 \mathrm{mM}$ EDTA; and $0.1 \%$ Tween-20), after which the four extracts from each cell type were combined before enzyme inactivation $\left(75^{\circ} \mathrm{C}, 15 \mathrm{~min}\right)$. After washing, a double-stranded DNA linker was ligated to the $5^{\prime}$ end of the cDNA in order to facilitate subsequent nongene template PCR amplification using oligonucleotide primers that annealed to the $5^{\prime}$ end linker sequence or the polyA tail in the $3^{\prime}$ end, respectively. PCR amplification of suspended magnetic beads harboring the cDNA was performed with Advantage 2 Polymerase Mix (BD Biosciences-Clontech, San Diego, CA, U.S.A.) with conditions of $160 \mathrm{~s}$ at $94^{\circ} \mathrm{C} ; 35$ cycles of $20 \mathrm{~s}$ at $94^{\circ} \mathrm{C}, 20 \mathrm{~s}$ at $50^{\circ} \mathrm{C}$, and $120 \mathrm{~s}$ at $72^{\circ} \mathrm{C}$; followed by $5 \mathrm{~min}$ of incubation at $72^{\circ} \mathrm{C}$.

\section{Hybridization.}

Samples were hybridized in random order to 12 Gatersleben barley PGRC1 $10 \mathrm{~K}$ arrays produced on the same day. Briefly, PCR products were purified using a PCR purification kit (Qiagen, Hilden, Germany) and $4 \mu$ l of each sample was radioactively labeled using a Megaprime kit (Amersham Pharmacia Biotech, Piscataway, NJ, U.S.A.). After use of a nucleotide removal kit (Qiagen), labeled samples were added to tubes containing nylon filter arrays and $20 \mathrm{ml}$ of hybridization mix containing $\mathrm{NaCl}(1 \mathrm{M})$, sodium dodecyl sulfate (SDS) $(0.8 \%)$, dextransulfat $(10 \%)$, salmon sperm DNA $(100 \mu \mathrm{g} / \mathrm{ml})$, and T7 primer $(1 \mu \mathrm{M})$, and hybridization was performed at $65^{\circ} \mathrm{C}$ for $20 \mathrm{~h}$. Filters then were washed in stringent washing buffer $(0.1 \times \mathrm{SSC}[1 \times \mathrm{SSC}$ is $0.15 \mathrm{M} \mathrm{NaCl}$ plus $0.015 \mathrm{M}$ sodium citrate] and $0.1 \%$ SDS), wrapped in saran wrap, and exposed to phosphorimager screens.

\section{Scanning, image, and data processing.}

Hybridized arrays were exposed for 72 to $96 \mathrm{~h}$ to two storage phosphor screens and scanned at $100-\mu \mathrm{m}$ resolution on a phosphorimager (Fujix BAS 1000; Fuji Photo-Film, Tokyo). Spot intensities were extracted from the resulting images using ArrayVision software (Imaging Research, St. Catharines, Canada). Spot intensities were corrected for radiation spill-over effects (Machl et al. 2002) and outliers, and their variances were stabilized using $\log _{2}$-transformation and made comparable between arrays by median normalization (Supplement 1). Before testing for differential expression, genes with constant expression were removed. The 5,519 remaining barley genes all had a coefficient of variation larger than 0.3 among the nine samples, and had an expression higher than 0 (the median intensity on the array) in at least three samples. All raw and normalized data are stored in the ArrayExpress database, accession number E-MEXP-457.

\section{Division between plant and fungal genes.}

The barley cDNA libraries used to design the $10 \mathrm{~K}$ array, especially the library made from $B$. graminis f. sp. hordeiinoculated barley, may contain some fungal sequences. A gene spotted on the $10 \mathrm{~K}$ array was classified as fungal if it showed preferential high homology (using both blastn and tblastx) to fungal sequences (an $E$ value less than $10^{-20}$ ) over plant sequences (no hits less than $10^{-4}$ ). Here, the fungal sequences were from the Cogeme database and the plant sequences constitute the rice (The Institute for Genomic Research Oryza sativa database) and Arabidopsis (The Arabidopsis Information Resource website) genomes combined.

\section{ACKNOWLEDGMENTS}

This work was supported by The Danish Agricultural and Veterinary Research Council and the Danish Directorate for Food, Fisheries and Agribusiness and by Defra (AR0712), U.K. The authors are grateful to Dr. Axel Himmelbach, IPK, Gatersleben for providing expression data on the 332 candidate genes in bulk extracts of barley for validation of the singlecell data.

\section{LITERATURE CITED}

Altschul, S. F., Gish, W., Miller, W., Myers, E. W., and Lipman, D. J. 1990. Basic local alignment search tool. J. Mol. Biol. 215:403-410.

Ashburner, M., Ball, C. A., Blake, J. A., Botstein, D., Butler, H., Cherry, J. M., Davis, A. P., Dolinski, K., Dwight, S. S., Eppig, J. T., Harris, M. A., Hill, D. P., Issel-Tarver, L., Kasarskis, A., Lewis, S., Matese, J. C., Richardson, J. E., Ringwald, M., Rubin, G. M., and Sherlock, G. 2000. Gene ontology: Tool for the unification of biology. The Gene Ontology Consortium. Nat. Genet. 25:25-29.

Benjamini, Y., and Hochberg, Y. 1995. Controlling the false discovery rate-A practical and powerful approach to multiple testing. J. R. Stat. Soc. 57:289-300.

Brandt, S., Kehr, J., Walz, C., Imlau, A., Willmitzer, L., and Fisahn, J. 1999. A rapid method for detection of plant gene transcripts from single epidermal, mesophyll and companion cells of intact leaves. Plant $\mathrm{J}$. 20:245-250.

Brandt, S., Kloska, S., Altmann, T., and Kehr, J. 2002. Using array hybridization to monitor gene expression at the single cell level. J. Exp. Bot. 53:2315-2323.

Caldo, R. A., Nettleton, D., and Wise, R. P. 2004. Interaction-dependent gene expression in Mla-specified response to barley powdery mildew. Plant Cell 16:2514-2528.

Close, T. J., Wanamaker, S. I., Caldo, R. A., Turner, S. M., Ashlock, D. A., Dickerson, J. A., Wing, R. A., Muehlbauer, G. J., Kleinhofs, A., and Wise, R. P. 2004. A new resource for cereal genomics: $22 \mathrm{~K}$ barley GeneChip comes of age. Plant Physiol. 134:960-968.

Collinge, D. B., Gregersen, P. L., and Thordal-Christensen, H. 1994. The induction of gene expression in response to pathogenic microbes. Pages 
391-433 in: Mechanisms of Plant Growth and Improved Productivity: Modern Approaches. A. S. Basra, ed. Marcel Dekker,New York.

Collins, N. C., Thordal-Christensen, H., Lipka, V., Bau, S., Kombrink, E., Qiu, J. L., Huckelhoven, R., Stein, M., Freialdenhoven, A., Somerville, S. C., and Schulze-Lefert, P. 2003. SNARE-protein-mediated disease resistance at the plant cell wall. Nature 425:973-977.

Cox, T. F., and Cox, M. A. A. 2000. Multidimensional Scaling, 2nd ed. Chapman \& Hall/CRC, London.

Danial, N. N., Gramm, C. F, Scorrano, L., Zhang, C., Krauss, S., Ranger, A. M., Datta, S. R., Greenberg, M. E., Licklider, L. J., Lowell, B. B., Gygi, S. P., and Korsmeyer, S. J. 2003. BAD and glucokinase reside in a mitochondrial complex that integrates glycolysis and apoptosis. Nature 424:952-956

Ellgaard, L., and Frickel, E. M. 2003. Calnexin, calreticulin, and ERp57: Teammates in glycoprotein folding. Cell. Biochem. Biophys. 39:223247.

Forkmann, G., and Heller, W. 1999. Biosynthesis of flavonoids. Pages 713-748 in: Polyketides and Other Secondary Metabolites Including Fatty Acid and Their Derivatives, Vol. 1. U. Sankawa, ed. Elsevier, Amsterdam

Foyer, C. H., and Noctor, G. 2005. Oxidant and antioxidant signaling in plants: A re-evaluation of the concept of oxidative stress in a physiological context. Plant Cell Environ. 28:1056.

Gentleman, R. C., Carey, V. J., Bates, D. M., Bolstad, B., Dettling, M., Dudoit, S., Ellis, B., Gautier, L., Ge, Y., Gentry, J., Hornik, K., Hothorn, T., Huber, W., Iacus, S., Irizarry, R., Leisch, F., Li, C., Maechler, M., Rossini, A.J., Sawitzki, G., Smith, C., Smyth, G., Tierney, L., Yang, J. Y., and Zhang, J. 2004. Bioconductor: Open software development for computational biology and bioinformatics. Genome Biol. 5:R80.

Gjetting, T., Carver, T. L. W., Skøt, L., and Lyngkjær, M. F. 2004. Differential gene expression in individual papilla-resistant and powdery mildew-infected barley epidermal cells. Mol. Plant-Microbe. Interact. 17:729-738

Glazebrook, J. 2001. Genes controlling expression of defense responses in Arabidopsis - 2001 status. Curr. Opin. Plant Biol. 4:301-308.

Green, J. R., Carver, T. L. W., and Gurr, S. J. 2002. The formation and function of infection and feeding structures. Pages 107-125 in: The Powdery Mildews: A Comprehensive Treatise. R. R. Belanger, W. R. Bushnell, A. J. Dik, and T. L. W. Carver, eds. American Phytopathological Society Press, St. Paul, MN, U.S.A.

Gregersen, P. L., Thordal-Christensen, H., Forster, H., and Collinge, D. B. 1997. Differential gene transcript accumulation in barley leaf epidermis and mesophyll in response to attack by Blumeria graminis f. sp. hordei (syn. Erysiphe graminis f. sp. hordei). Physiol. Mol. Plant Pathol 51:85-97.

Holcik, M., and Sonenberg, N. 2005. Translational control in stress and apoptosis. Nat. Rev. Mol. Cell Biol. 6, 318-327.

Hu, G. G., and Rijkenberg, F. H. J. 1998. Subcellular localization of beta1,3-glucanase in Puccinia recondita f. sp. tritici-infected wheat leaves. Planta 204:324-334.

Hückelhoven, R., and Kogel, K. H. 1998. Tissue-specific superoxide generation at interaction sites in resistant and susceptible near-isogenic barley lines attacked by the powdery mildew fungus (Erysiphe graminis $\mathrm{f}$. sp. hordei). Mol. Plant-Microbe. Interact. 11:292-300.

Inoki, K., Ouyang, H., Li, Y., and Guan K. 2005. Signaling by target of rapamycin proteins in cell growth control. Microbiol. Mol. Biol. Rev. 69:79-100

Iscove, N. N., Barbara, M., Gu, M., Gibson, M., Modi, C., and Winegarden, N. 2002. Representation is faithfully preserved in global cDNA amplified exponentially from sub-picogram quantities of mRNA. Nat. Biotechnol. 20:940-943.

Kalinski, A., Rowley, D. L., Loer, D. S., Foley, C., Buta, G., and Herman, E. M. 1995. Binding-protein expression is subject to temporal, developmental and stress-induced regulation in terminally differentiated soybean organs. Planta 195:611-621.

Kanehisa, M., and Goto, S. 2000. KEGG: Kyoto Encyclopedia of Genes and Genomes. Nucleic Acids Res. 28:27-30.

Karrer, E. E., Lincoln, J. E., Hogenhout, S., Bennett, A. B., Bostock, R. M., Martineau, B., Lucas, W. J., Gilchrist, D. G., and Alexander, D. 1995. In situ isolation of mRNA from individual plant cells: Creation of cell-specific cDNA libraries. Proc. Natl. Acad. Sci. U.S.A. 92:38143818.

Kim, C. Y., Koo, Y. D., Jin, J. B., Moon, B. C., Kang, C. H., Kim, S. T., Park, B. O., Lee, S. Y., Kim, M. L., Hwang, I., Kang, K. Y., Bahk, J. D., Lee, S. Y. and Cho, M. J. 2003. Rice C2-domain proteins are induced and translocated to the plasma membrane in response to a fungal elicitor. Biochemistry 42:11625-11633.

Künne, C., Lange, M., Funke, T., Miehe, H., Thiel, T., Grosse, I., and Scholz, U. 2005. CR-EST: A resource for crop ESTs. Nucleic Acids Res. 33:D619-D621.
Lam, E., and del Pozo, O. 2000. Caspase-like protease involvement in the control of plant cell death. Plant Mol. Biol. 44:417-428.

Lyngkjaer, M. F., and Carver, T. L. W. 1999. Induced accessibility and inaccessibility to Blumeria graminis f. sp. hordei in barley epidermal cells attacked by a compatible isolate. Physiol. Mol. Plant Pathol. 55:151-162.

Machl, A. W., Schaab, C., and Ivanov, I. 2002. Improving DNA array data quality by minimising 'neighbourhood' effects. Nucleic Acids Res. 30:e127.

Mendgen, K., and Hahn, M. 2002. Plant infection and the establishment of fungal biotrophy. Trends Plant Sci. 7:352-356.

Meyermans, H., Morreel, K., Lapierre, C., Pollet, B., De Bruyn, A., Busson, R., Herdewijn, P., Devreese, B., Van Beeumen, J., Marita, J. M., Ralph, J., Chen, C., Burggraeve, B., Van Montagu, M., Messens, E., and Boerjan, W. 2000. Modifications in lignin and accumulation of phenolic glucosides in poplar xylem upon down-regulation of caffeoyl-coenzyme A $O$-methyltransferase, an enzyme involved in lignin biosynthesis. J. Biol. Chem. 275:36899-36909.

Møller, I. M. 2001. Plant mitochondria and oxidative stress: Electron transport, NADPH turnover, and metabolism of reactive oxygen species. Annu. Rev. Plant Physiol. Plant Mol. Biol. 52:561-591.

Mould, M. J. R., Xu, T., Barbara, M., Iscove, N. N., and Heath, M. C. 2003. cDNAs generated from individual epidermal cells reveal that differential gene expression predicting subsequent resistance or susceptibility to rust fungal infection occurs prior to the fungus entering the cell lumen. Mol. Plant-Microbe. Interact. 16:835-845.

Nagano, F., Orita, S., Sasaki, T., Naito, A., Sakaguchi, G., Maeda, M., Watanabe, T., Kominami, E., Uchiyama, Y., and Takai, Y. 1998. Interaction of Doc2 with tctex-1, a light chain of cytoplasmic dynein. Implication in dynein-dependent vesicle transport. J. Biol. Chem. 273:3006530068.

Panstruga, R. 2003. Establishing compatibility between plants and obligate biotrophic pathogens. Curr. Opin. Plant Biol. 6:320-326.

Philchenkov, A. 2004. Caspases: Potential targets for regulating cell death. J. Cell Mol. Med. 8:432-444.

Prats, E., Mur, L. A. J., Sanderson, R., and Carver, T. L. W. 2005. Nitric oxide contributes both to papilla-based resistance and the hypersensitive response in barley attacked by Blumeria graminis f. sp. hordei. Mol. Plant Pathol. 6:65-78.

Puig, A., and Gilbert, H. F. 1994. Anti-chaperone behavior of BiP during the protein disulfide isomerase-catalyzed refolding of reduced denatured lysozyme. J. Biol. Chem. 269:25889-25896.

Ravagnan, L., Gurbuxani, S., Susin, S. A., Maisse, C., Daugas, E. Zamzami, N., Mak, T., Jaattela, M., Penninger, J. M., Garrido, C., and Kroemer, G. 2001. Heat-shock protein 70 antagonizes apoptosis-inducing factor. Nat. Cell Biol. 3:839-843.

Rushton, P. J., and Somssich, I. E. 1999. Transcriptional regulation of plant genes responsive to pathogens and elicitors. Pages 251-274 in: Plant-Microbe Interaction 4. G. Stacey and N. Keen, eds. American Phytopathological Society Press, St. Paul, MN, U.S.A

Schlumpberger, M., Schaeffeler, E., Straub, M., Bredschneider, M., Wolf, D. H., and Thumm, M. 1997. AUT1, a gene essential for autophagocytosis in the yeast Saccharomyces cerevisiae. J. Bacteriol. 179:10681076

Schulze-Lefert, P. 2004. Knocking on heaven's wall: Pathogenesis of and resistance to biotrophic fungi at the cell wall. Curr. Opin. Plant Biol. 7:377-383.

Smith, A. M. O., Ratcliffe, R. G., and Sweetlove, L. J. 2004. Activation and function of mitochondrial uncoupling protein in plants. J. Biol. Chem. 279:51944-51952.

Smyth, G. K. 2004. Linear models and empirical bayes methods for assessing differential expression in microarray experiments. Stat. Appl. Genet. Mol. Biol. 3:article 3. Online publication.

Somerville, C., Bauer, S., Brininstool, G., Facette, M., Hamann, T., Milne, J., Osborne, E., Paredez, A., Persson, S., Raab, T., Vorwerk, S., and Youngs, H. 2004. Toward a systems approach to understanding plant cell walls. Science 306:2206-2211.

Sreenivasulu, N., Altschmied, L., Panitz, R., Hahnel, U., Michalek, W., Weschke, W., and Wobus, U. 2002. Identification of genes specifically expressed in maternal and filial tissues of barley caryopses: A cDNA array analysis. Mol. Genet. Genomics 266:758-767.

Suzuki, S., Komiya, Y., Mitsui, T., Tsuyumu, S., Kunoh, H., Carver, T. L. W., Nicholson, R. L. 1998. Release of cell wall degrading enzymes from conidia of Blumeria graminis on artificial substrata. Ann. Phytopathol. Soc. Jpn. 64:160-167.

Theis, T., and Stahl, U. 2004. Antifungal proteins: Targets, mechanisms and prospective applications. Cell. Mol. Life Sci. 61:437-455.

Thimm, O., Bläsing, O., Gibon, Y., Nagel, A., Meyer, S., Krüger, P., Selbig, J., Müller, L. A., Rhee, S. Y., and Stitt, M. 2004. MAPMAN: A userdriven tool to display genomics data sets onto diagrams of metabolic pathways and other biological processes. Plant J. 37:914-939. 
Thordal-Christensen, H., Zhang, Z. G., Wei, Y. D., and Collinge, D. B. 1997. Subcellular localization of $\mathrm{H}_{2} \mathrm{O}_{2}$ in plants. $\mathrm{H}_{2} \mathrm{O}_{2}$ accumulation in papillae and hypersensitive response during the barley-powdery mildew interaction. Plant J. 11:1187-1194.

Voegele, R. T., Hahn, M., Lohaus, G., Link, T., Heiser, I., and Mendgen, K. 2005. Possible roles for mannitol and mannitol dehydrogenase in the biotrophic plant pathogen Uromyces fabae. Plant Physiol. 137:190198.

Vogel, J. P., Raab, T. K., Schiff, C., and Somerville, S. C. 2002. PMR6, a pectate lyase-like gene required for powdery mildew susceptibility in Arabidopsis. Plant Cell 14:2095-2106.

Vogel, J. P., Raab, T. K., Somerville, C. R., and Somerville, S. C. 2004. Mutations in PMR5 result in powdery mildew resistance and altered cell wall composition. Plant J. 40:968-978.

Walther-Larsen, H., Brandt, J., Collinge, D. B., and Thordal-Christensen, H. 1993. A pathogen-induced gene of barley encodes a hsp90 homolog showing striking similarity to vertebrate forms resident in the endoplasmic-reticulum. Plant Mol. Biol. 21:1097-1108.

Wang, S., Liu, Y., Adamson, C. L., Valdez, G., Guo, W., and Hsu, S. C. 2004. The mammalian exocyst, a complex required for exocytosis, inhibits tubulin polymerization. J. Biol. Chem. 279:35958-35966.

Weinberger, A., and Gerst, J .E. 2004. Regulation of SNARE assembly by protein phosphorylation. Top. Curr. Genet. 10:145-170.

Yang, K. Y., Im, Y. J., Chung, G. C., and Cho, B. H. 2002. Activity of the Arabidopsis blue copper-binding protein gene promoter in transgenic tobacco plants upon wounding. Plant Cell. Rep. 20:987-991.

Zeyen, R. J., Carver, T. L. W., and Lyngkjær, M. F. 2002. The formation and role of papillae. Pages 107-125 in: The Powdery Mildews: A Comprehensive Treatise. R. R. Belanger, W. R. Bushnell, A. J. Dik, and T. L. W. Carver, eds. American Phytopathological Society Press, St. Paul, MN, U.S.A.

Zhang, Z., Henderson, C., and Gurr, S. J. 2004. Blumeria graminis secretes an extracellular catalase during infection of barley: Potential role in suppression of host defence. Mol. Plant Pathol. 5:537-547.

Zierold, U., Scholz, U., and Schweizer, P. 2005. Transcriptome analysis of mlo-mediated resistance in the epidermis of barley. Mol. Plant Pathol. 6:139-151.

Zimmermann, P., Hirsch-Hoffmann, M., Hennig, L., and Gruissem, W. 2004. GENEVESTIGATOR. Arabidopsis microarray database and analysis toolbox. Plant Physiol. 136:2621-2632.

\section{AUTHOR-RECOMMENDED INTERNET RESOURCES}

ArrayExpress database: www.ebi.ac.uk/arrayexpress

GenBank Blast database: www.ncbi.nlm.nih.gov/BLAST/

The Arabidopsis Information Resource:

ftp.arabidopsis.org/home/tair/home/tair/Sequences/blast_datasets/

TIGR barley gene index database:

www.tigr.org/tigr-scripts/tgi/T_index.cgi?species=barley

Cogeme database: cogeme.ex.ac.uk/sequence.html

The Institute for Genomic Research (TIGR) database: ftp://ftp.tigr.org/pub/data/Eukaryotic_Projects/o_sativa/annotation_dbs/ pseudomolecules 